\title{
Lähdetekstien vaikutus Mikael Agricolan tekstien vihastumista ilmaisevien verbien rektioihin
}

\section{$\mathbf{y}$}

Kun halutaan tarkastella kieltenvälistä vaikutusta vanhassa kirjasuomessa, Mikael Agricolan tekstit tarjoavat kiinnostavan ja monipuolisen tutkimusaineiston. Teokset on käännetty useista erikielisistä lähdeteksteistä, jotka ovat vaikuttaneet niihin monin tavoin. Esimerkiksi Uusi testamentti (1548) on käännetty teoksen saksan-, ruotsin-, latinan- ja kreikankielisistä versioista.

Tutkimuskohteenani ovat vihastumista ilmaisevien verbien rektiot. ${ }^{1}$ Keskeinen tutkimuskysymys on, millaisin täydennyksin vihastumisverbien ärsyke on ilmaistu. Ärsyke on nimitys semanttiselle roolille, jota edustaa tunneverbien yhteydessä tunteen aiheuttava ilmiö tai olio (VISK, määritelmät s.v. ärsyke). Nykysuomessa vihastumista ilmaisevien verbien rektioina ovat allatiivi (vihastua jollekin/jollekulle), illatiivi (vihastua johonkin/johonkuhun) ja elatiivi (vihastua jostakin). Agricolan teksteissä kyseisten verbien rektio on kuitenkin nykykieltä moninaisempi: rektiona on useimmiten adpositio, harvemmin sijamuoto. Koska useat Agricolan teksteissä esiintyvät rektiot poikkeavat nykysuomesta, herää kysymys mahdollisista kontaktivaikutuksen jättämistä jäljistä.

Tutkimus tuo lisätietoa Agricolan teksteistä ja vanhan kirjasuomen ajan kielikontakteista. Hyödynnän aiem-

1. Kiitän arvioijia heidän tarkasta työstään. Kirjoitus on muokkautunut ja parantunut heidän rakentavien kommenttiensa ansiosta. paa tietoa keskiajan ja uuden ajan taitteessa käytetyistä käännösmenetelmistä ja paneudun Agricolan tekstien käännösratkaisuihin vertailemalla niitä käännösten lähdeteksteihin. Selvitän, millaisia ovat ne erikielisten lähdetekstien rakenteet, jotka ovat toimineet käännöstyössä suomenkielisten rakenteiden malleina. Pääpaino on Agricolan teksteissä ja lähdetekstien vaikutuksen selvittämisessä, mutta tarkastelen vihastumista ilmaisevien verbien rektioita myös myöhemmissä raamatunsuomennoksissa. Tutkimus tuo siten uutta tietoa myös lähdekielten vaikutuksen laajuudesta ja vihastumisverbien rektioiden muuttumisesta Raamatun kielessä.

\section{Mikael Agricola raamatunsuomentajana}

Pääosa Agricolan teksteistä on Raamatun tekstien käännöksiä. Uskonnollisten tekstien ja erityisesti Raamatun kääntämisessä on omat erityispiirteensä. Raamatun kääntämisessä oli tärkeää, että alkutekstiä tulkittiin mahdollisimman uskollisesti, ja monet tutkimukset osoittavat, että Agricolan raamatunsuomennos on huolellista ja pikkutarkkaa työtä. Siinä näkyy uskollisuus alkuperäisille lähdeteksteille: tekstiin ei ole lisätty juuri mitään eikä siitä ole myöskään jätetty pois juuri mitään. (Itkonen-Kaila 1997: 16, 58, 72; ks. myös Heininen 1992, 1993; Salmi 2010.) Käännöstyössä on kuitenkin pyritty ajan luterilaisen ihanteen mukaan luontevaan 
kansankieleen (Tarkiainen \& Tarkiainen 1985: 181).

Agricolan aikaan Raamattua käännettiin kansankielille osin suoraan alkukielistä2, osin muiden kielten kautta. Keskiajalla Raamatusta oli yleisesti käytössä latinankielinen Vulgata; uskonpuhdistuksen myötä Lutherin saksannoksesta tuli tärkeä esikuva kääntäjille. Myös Erasmus Rotterdamilaisen Uuden testamentin latinan- ja kreikankielinen versio ja hänen raamatunselityksensä huomioitiin suomenkielisessä raamatunkäännöksessä. Näiden lisäksi keskeisiä lähdetekstejä suomennoksessa olivat ruotsinkieliset raamatunkäännökset. (Häkkinen 2007: 26-27; Itkonen-Kaila 2007: 57.) Esittelen Agricolan käyttämät lähdetekstit tarkemmin tuonnempana.

Siitä, että Agricola on kääntäessään vertaillut käyttämiensä lähdetekstien erikielisiä versioita ja jopa teosten eri painoksia, on paljon tutkimustietoa (ks. esim. Heininen 1992: 247-248; 1993: 122-123; 1999: 274-275). Raamatunsuomennoksissa on runsaasti kohtia, jotka ovat yhtäpitäviä Lutherin saksannoksen sekä ruotsinkielisen kokoraamatun ja Uuden testamentin ruotsinnoksen kanssa mutta joiden sananmuoto eroaa latinan- ja kreikankielisten lähteiden vastaavista kohdista. Teksteissä on paljon tapauksia, joissa Lutherin sananmuoto on ainoana mallina Agricolan käännökselle. Sen sijaan tapauksia, joissa mallina olisi kiistatta vain ruotsinkielinen käännös, on vähän, sillä ruotsinkieliset käännökset noudattavat pitkälti Lutherin käännöstä. Myös suoraan klassisista kielistä peräisin olevia piirteitä, jotka ilmaistaan saksassa ja ruotsissa selvästi eri tavalla kuin klassisissa kielissä, on Agricolan teksteissä niukasti. (Schmeidler 1970: 366; ItkonenKaila 1997: 11-16, 57-65, 71-77, 87, 97, 104; 2007: 57-58; Salmi 2010: 235, 259, 344.)

2. Vanhan testamentin alkukielet ovat heprea (ja aramea), ja Uuden testamentin alkukieli on kreikka.
On kuitenkin huomionarvoista, että raamatunsuomennoksissa yhdenkin jakeen sisällä voi olla usean eri lähdetekstin vaikutusta (Schmeidler 1970: 366; ItkonenKaila 1997: 14, 16) ja, kuten tämäkin tutkimus osoittaa, yksittäiset rakenteiden osatkin voivat palautua erikielisiin teksteihin (ks. esim. 10 s. 233; vastaavia esimerkkejä esittää myös Salmi 2010).

\section{Tutkimusaineisto, metodi ja keskeiset käsitteet}

Olen poiminut tutkimusaineiston Mikael Agricolan teosten morfosyntaktisesta tietokannasta. Aineisto sisältää vain ne tunneverbien esiintymät, joissa on kokijan lisäksi ilmaistuna tunteen aiheuttava ärsyke, kuten eipe hen heille wihastu (A-III-434-[Ps-149:0]; tunneverbeistä ks. erit. Siiroinen 2001; Murmann 2018). Rakenteet, joissa on verbin lisäksi vain kokija, kuten Ele nin wihastu / ettes itzeki paha teet (A-III-261-[Ps-37:8]), olen rajannut aineiston ulkopuolelle, koska huomion kohteena on se, miten ärsyketäydennystä ilmaistaan. Ison suomen kieliopin mukaan ärsykettä ilmaistaan nykysuomessa lähes kaikkien tunneverbien yhteydessä elatiivimuotoisella lausekkeella, kuten suuttua loukkaantua hermostua jostakin. Suuttumisverbit voivat lisäksi saada allatiivisijaisen ihmistarkoitteisen täydennyksen, kuten suuttua jollekulle. Ärsykettä ilmaistaan myös illatiivisijaisella täydennyksellä, kuten suuttua johonkin. (VISK $\$ 466$.)

Agricolan teksteissä tietyssä sijamuodossa olevan täydennyksen tai tietyn adpositiotäydennyksen saavia vihastumista ilmaisevia verbejä ovat ainakin ${ }^{3}$ julmasanasta johdetut verbit julmaantua, julmastua ja julmistua (yht. 10 es.), kyrkäs-

3. On mahdollista, että Agricolan teksteissä ilmaistaan vihastumista aineistossa olevien verbien lisäksi esimerkiksi jollakin kyrkästyä-verbin tyyppisellä verbillä, jota ei osaa etsiä, jollei tiedä tällaista verbiä olevan Agricolan kielessä. 
tyä 'vihastua' (VKS s.v. kyrkästyä; 2 es.), suuttua (4 es.) ja vihastua (24 es.).

Tutkimuksen keskeisenä metodina on vertailu. Tarkastelen Agricolan käännösratkaisuja rinnakkain käännösten lähdetekstien kanssa. Monet yksittäiset rakenteet on käännetty siten, että kohdekielessä jo olemassa olevat rakenteet ovat saaneet uuden merkityksen ja uuden funktion lähdekielten vastaavien rakenteiden mukaan. Tällaista kieltenvälistä vaikutusta kutsutaan interferenssiksi. Käännöstieteessä sillä tarkoitetaan tilapäistä kieltenvälistä vaikutusta, joka rajoittuu käännettyihin teksteihin eikä leviä käännöksistä ja vakiinnu kieleen. (Paulasto, Kolehmainen, Kumpulainen, Meriläinen \& Riionheimo 2014: 422, 425.)

Tässä tutkimuksessa kontaktilähtöisiksi katsotaan sellaiset muutokset, joille on rakenteen ja merkityksen kannalta selvä vastine lähdekielessä ja joiden toteutumista voidaan pitää vähemmän todennäköisenä ilman kielikontaktin vaikutusta. Kontaktivaikutus on todennäköinen, kun rektiot ovat toisiaan vastaavat. Interferenssistä on todennäköisesti kyse esimerkiksi silloin, kun Agricolan kielessä on rektiona päälle-adpositio ja lähdeteksteissä 'päälle'-merkityksinen prepositio (über, över, (up)på, super). Vastaavuudet on esitetty taulukossa 3 (s. 227). Kontaktivaikutuksesta ei oleteta olevan kyse silloin, kun Agricolan suomennoksessa rektiona on sijamuoto ja lähdeteksteissä adpositio tai päinvastoin. Kontaktivaikutus voi olla monilähtöinen: jo aiemman tutkimuksen mukaan on selvää, että yksittäisen lähdetekstin vaikutuksesta voidaan puhua vain silloin, jos tiettyä ilmaisutapaa ei esiinny muissa lähteissä (ks. esim. Schmeidler 1970: 366; Itkonen-Kaila 1997: 14, 16; Riionheimo 2007: 260-266; 2013).

4. Kyrkästyä-verbi esiintyy vain Agricolan teksteissä, ja se on korvattu Bibliasta (1642) alkaen ilmauksilla närkästyä ja olla vihainen. Verbiä ei esiinny myöskään Suomen murteiden sanakirjassa.
Nykykäsityksen mukaan kielensisäinen motivaatio ja kielikontaktit ovat yhdessä muutosten ja uusien ilmaisukeinojen taustalla eikä niitä voida erottaa ehdottomasti toisistaan (ks. Kolehmainen \& Nordlund 2011). Kontaktivaikutuksen vahvistamiseksi tarvittaisiin siis tieto siitä, että rakennetta ei ole esiintynyt kielessä jo aiemmin. (Thomason 2001: 91-95.) Tämän tutkimuksen aineiston avulla ei kuitenkaan voida päätellä, miten mahdollinen kielensisäinen motivaatio on vaikuttanut rakenteiden käyttöön, sillä Agricolaa aikaisempia suomeksi kirjoitettuja tekstejä ei juuri ole.

Agricolan käyttämät lähdetekstit muodostavat vertailuaineiston Agricolan teksteille, ja tarkastelen niiden avulla lähdetekstien vihastumisverbien rektioiden vaikutusta suomennokseen. Erityisesti Uuden testamentin osalta lähdetekstejä on useita. Agricola kirjoittaa esipuheessaan, että käännöksen pohjana ovat olleet kreikan-, latinan-, saksan- ja ruotsinkieliset tekstit. Arthur Hjeltin (1909: 7-14) mukaan Agricola käytti seuraavia lähdetekstejä:

1) Erasmus Rotterdamilaisen Uuden testamentin kreikankielinen teksti vuodelta 1535 (= KR)

2) Erasmuksen latinankielinen käännös vuoden 1527 tai 1535 painoksena (= ER)

3) latinankielinen raamatunkäännös Vulgata $(=\mathrm{V})$

4) Lutherin saksalainen kokoraamattu, vuoden 1539 painos, ja Uuden testamentin vuoden 1544 painos $(=\mathrm{L})$

5) vuonna 1526 ilmestynyt ruotsinkielinen Uusi testamentti $(=\mathrm{NT})$

6) vuonna 1541 ilmestynyt ruotsinkielinen kokoraamattu (= GVB).

Vanhan testamentin osalta lähdetekstejä ovat Vulgata, Lutherin saksankielinen Raamattu ja vuoden 1541 ruotsinkielinen Raamattu (Itkonen-Kaila 2007: 57). Vanhan testamentin alkukieli heprea on vaikuttanut ensimmäisiin Vanhan testamentin suomennoksiin lähinnä välillisesti, 
saksan ja latinan kautta (Kela 2007: 48). ${ }^{5}$ Rukouskirjan vertailuaineistona ovat suomennettujen raamatuntekstien osalta yllä esitellyt lähdetekstit sekä Jaakko Gummeruksen (1955) ja Juhani Holman (2008) tutkimusten kautta löytyvät lähdetekstit. ${ }^{6}$

Lähdetekstien vaikutuksen lisäksi selvitän, miten tarkasteltavat kohdat on suomennettu myöhemmissä raamatunkäännöksissä (1642, 1776, 1933/38 ja 1992) eli ovatko rakenteet säilyneet ja siirtyneet myöhempiin laitoksiin. On olennaista tiedostaa, että suomen kielen standardointi on vaikuttanut vieraiksi koettujen rakenteiden käyttöön: Jo Bibliassa (1642) oli pyrkimyksenä karsia Agricolan käännöksen vierasperäisyydet. Edelleen monet 180o-luvun kielenuudistajat yrittivät tehdä suomen kielestä "puhtaan" poistamalla siitä vierasperäisiksi katsomiaan rakenteita; pyrkimyksenä oli minimoida variaatio ja epäsymmetrisyys. (Laitinen 2004: 247-248.) Myös monet adpositiorektiot katsottiin vieraiksi (ks. esim. Salmi 2010: 206-314), mikä selittää osaltaan niiden käytössä tapahtuneita muutoksia.

\section{Vihastumisverbien rektiot Agricolan teoksissa ja rektioiden muutokset Raamatun kielessä}

Agricolan kielessä vihastumisverbien rektiot ovat moninaisia, ja samakin verbi voi saada useita eri rektioita, kuten kyrkästyä jonkun päälle tai jollekulle. Useimmiten rektiona on adpositio: päälle, ylitse, vastaan, vastoin ja kanssa, mutta vihastumisen ärsykettä ilmaistaan myös sijamuodoilla. Nykysuomen mukaisten allatiivin,

5. Aiemmin on ajateltu, että Agricolalla olisi ollut apunaan hepreaa osaava kääntäjä tai kääntäjiä (Tarkiainen \& Tarkiainen 1985: 239; Häkkinen 1994: 84-86), mutta Simo Heinisen (1999: 275) mukaan ei ole näyttöä siitä, että hepreankielistä tekstiä olisi käytetty Rukouskirjan vanhatestamentillisten tekstien tai Psalttarin lähteenä.

6. Käsikirjan ja Messun lähdetekstejä ei ole analysoitu esiintymien vähäisyyden vuoksi. illatiivin ja elatiivin lisäksi Agricolalla on kerran datiivigenetiivi- (vihastua jonkun) ja kerran partitiivirektio (vihastua jotakuta). Suuttua poikkeaa muista verbeistä, sillä se ei saa kertaakaan adpositiorektiota, vaan sen täydennys on aina tietyssä sijassa oleva nomini. Suuttua eroaa muista verbeistä myös siten, että se on vanha läpinäkymätön verbijohdos, jonka alkuperä on epävarma (SSA s.v. suuttua). Muut vihastumista ilmaisevat verbit ovat läpinäkyviä adjektiivikantaisia $s t U$ - tai $n t U$-johdoksia.

Vihastumisverbien rektioita on kaikissa muissa Agricolan teoksissa paitsi $\mathrm{Abc}$ kiriassa (1543), kuten taulukosta 1 (s. 226) näkyy. Vihastumisverbien adpositiorektioita on seitsemässä teoksessa ja sijamuotorektioita vain neljässä. Sijamuotorektiot keskittyvät monista eri lähteistä käännettyyn Rukouskirjaan (1544) ja Vanhan testamentin osia sisältävään teokseen Weisut ja ennustokset (1551). Rukouskirja on Raamattuun nähden vapaampaa käännöstä, mikä saattaa osaltaan selittää sijamuotorektioiden käyttöä lähdetekstien prepositiorektioiden mukaan käännettyjen adpositiorektioiden sijaan. Weisut ja ennustokset -teoksessa esiintyy eniten sijamuotorektioita, mutta teoksen adpositiorektioiden määrä on kuitenkin suurempi kuin sijamuotorektioiden. Rukouskirjan sijamuotorektioiden suhteellinen määrä rektioiden kokonaismäärään nähden on siis suurempi kuin Weisujen ja ennustosten sijamuotorektioiden suhteellinen määrä. On kuitenkin huomattava, että esiintymämäärät ovat hyvin pieniä, joten havainnot eivät kiinnostavuudestaan huolimatta mahdollista pitkälle menevien päätelmien tekemistä.

Kun verrataan Agricolan Uuden ja Vanhan testamentin osien käännösratkaisuja vuoden myöhempien raamatunsuomennosten vastaaviin kohtiin, saadaan selville, millaisia muutoksia rektioissa on tapahtunut Raamatun kielessä. Taulukosta 2 näkyy, että useimmat adpositiorektiot esiintyvät vain Agricolan käännöksissä. Vain päälle-adpositio on vihas- 
Taulukko 1.

Vihastumisverbien rektiot Agricolan kielessä teoksittain.

\begin{tabular}{lrr|r} 
Agricolan teos & Adpositio & Sijamuoto & Yhteensä \\
\hline Weisut ja ennustokset & 8 & 5 & 13 \\
\hline Rukouskirja & 4 & 4 & 8 \\
\hline Psalttari & 7 & & 7 \\
\hline Uusi testamentti & 5 & & 5 \\
\hline Käsikirja & 2 & & 2 \\
\hline Messu & 1 & 1 & 2 \\
\hline Profeetat & 2 & & 2 \\
\hline Piina & & 1 & 1 \\
\hline Yhteensä & 29 & 11 & 40 \\
\hline
\end{tabular}

Taulukko 2.

Vihastumista ilmaisevien verbien rektiot Agricolasta nykysuomeen.

\begin{tabular}{l|r|r|r|r|r} 
Rektio & Agricola & Biblia & 1776 & $1933 / 38$ & 1992 \\
\hline päälle & 10 & 13 & 13 & & \\
\hline ylitse & 8 & & & & \\
\hline vastaan & 2 & & & & \\
\hline kanssa & 2 & & & & \\
\hline tähden & & & 2 & & \\
\hline Allatiivi & 2 & 6 & 4 & & \\
\hline Elatiivi & 2 & 3 & 3 & & \\
\hline Illatiivi & 1 & 1 & 2 & 13 & 7 \\
\hline Genetiivi & 1 & 1 & & & \\
\hline Muu $^{7}$ & & 4 & 4 & 15 & 21 \\
\hline
\end{tabular}

tumisverbien rektiona vielä vuoden 1776 Raamatussa. Sen sijaan sijamuotorektioiden osuus kasvaa erityisesti 1900-luvun suomennoksissa. Hyödynnän taulukkoa tarkemmin kunkin rektion esittelyn yhteydessä, jolloin kuvaan myös rektiossa tapahtuneen muutoksen Agricolan raamatunteksteistä nykyiseen raamatunsuomennokseen.

7. Sisältää rakenteet, joissa vihastumista ilmaistaan muulla tavoin kuin tunneverbillä, kuten viha syttyy jotakuta/jotakin vastaan, tai ärsyke puuttuu kokonaan.

\section{Agricolan tekstien vihastumisverbien rektiot lähdekielten vaikutuksen näkökulmasta}

Lähdetekstien vaikutusta käännöksiin on havainnollista lähestyä taulukon 3 avulla. Taulukossa on esitetty Agricolan verbien rektiot ja lähdetekstien vastaavassa kohdassa olevat rakenteet kielittäin. Agricolan suomennoksen adpositioita perusmerkitykseltään vastaavat lähdetekstien prepositiot ja Agricolan sijamuotoja vastaavat lähdetekstien sijamuodot on lihavoitu. 
Taulukko 3.

Agricolan verbin rektio ja erikielisten lähdetekstien rektiot. ${ }^{8}$

\begin{tabular}{|c|c|c|c|c|}
\hline Agricola & Saksa & Ruotsi & Latina & Kreikka \\
\hline päälle & vber & offuer & dat & \\
\hline päälle & vber & $p a ̊$ & & \\
\hline päälle & vber & på/akk & dat & dat \\
\hline päälle & vber & $v p p a ̊$ & dat & \\
\hline päälle & vber & öffuer & dat & \\
\hline päälle & vber & öfuer & $a d$ & \\
\hline päälle & vber & öfuer & dat & \\
\hline päälle & vber & öfuer & in & \\
\hline päälle & vber & öfuer & contra & \\
\hline päälle & vber & öfuer & contra & \\
\hline päälle & mit & $p a ̊$ & dat & dat \\
\hline ylitse & vber & öfuer & super & \\
\hline ylitse & vber & öfuer & super & \\
\hline ylitse & vber & öfuer & contra & \\
\hline ylitse & vber & öfuer & in & \\
\hline ylitse & vber & öffuer & in & \\
\hline ylitse & darüber & theroffuer & muu & muu \\
\hline ylitse & $u m b$ & om & super & \\
\hline ylitse & muu & öfuer & muu & \\
\hline vastaan & vber & & contra & \\
\hline vastaan & vber & emoot/på & adversus/in & $\dot{\varepsilon} \pi i$ \\
\hline kanssa & mit & medh & adversum & \\
\hline kanssa & mit & öfuer & muu & \\
\hline Allatiivi & vber & dat/nom & dat & dat \\
\hline Allatiivi & vber & öfuer & dat & \\
\hline Elatiivi & dat & ther widh & muu & \\
\hline Elatiivi & muu & muu & muu & muu \\
\hline Elatiivi & muu & & & \\
\hline Illatiivi & $a n$ & til & nom & \\
\hline Genetiivi & gen & widh & gen & \\
\hline Partitiivi & muu & muu & muu & \\
\hline
\end{tabular}

8. Taulukon "muu" sisältää ne tapaukset, joissa lähdetekstin rakenne poikkeaa Agricolan käännöksestä niin, ettei siinä ole rakennetta 'vihastua' + ärsyke (ks. esim. 12 s. 235). Taulukossa on tyhjä kohta, jos tekstiä ei ole suomennettu kyseisenkielisestä lähdetekstistä. Taulukosta näkyy myös, millaisia muita käännösratkaisuja lähdetekstit olisivat tarjonneet. 
Kun tarkastellaan aineistoa kielittäin, huomataan, että ruotsinkielisissä lähdeteksteissä on Agricolan tekstien rakennetta vastaava rakenne 20 kertaa, saksankielisessä tekstissä 19 kertaa, latinankielisissä teksteissä 8 kertaa ja kreikankielisessä tekstissä vain kerran. Kreikan vaikutuksen vähäisyys selittyy pääosin sillä, että kreikankielinen teksti on vain Uuden testamentin lähdeteksti ja esiintymiä on Uudessa testamentissa vähän. Yleensä Agricolan käännösratkaisun paralleeli löytyy useammasta erikielisestä lähdetekstistä, kuten taulukosta 4 näkyy.

Taulukko 4.

Agricolan verbien rektioita vastaavat erikielisten lähdetekstien rektiot.

\begin{tabular}{lr} 
Lähdekieli & Määrä \\
\hline Saksa + ruotsi & 15 \\
\hline $\begin{array}{l}\text { Ei suoraa vastinetta } \\
\text { missään kielessä }\end{array}$ & 5 \\
\hline Latina & 3 \\
\hline Ruotsi & 2 \\
\hline Saksa + ruotsi + latina & 2 \\
\hline Saksa + latina & 1 \\
\hline Ruotsi + latina & 1 \\
\hline Ruotsi + latina + kreikka & 1 \\
\hline Saksa & 1 \\
\hline Yhteensä & 31 \\
\hline
\end{tabular}

Saksan- ja ruotsinkieliset käännökset ovat rektioiden osalta yleensä samanlaiset, ja Agricola noudattaa käännöksessään usein niiden mallia. Saksa on voinut toimia mallina Agricolan päälle-, ylitse- ja kanssa-adpositiorektiolle sekä datiivigenetiivirektiolle; ruotsinnokset ovat voineet olla malli päälle- ja ylitseadpositiorektioille. Ruotsinnoksissa on malli myös yhdelle vastaan- ja yhdelle kanssa-adpositiorektiolle.

Latinannokset poikkeavat edellä mainituista käännöksistä, sillä niissä verbin rektiona on usein joko datiivi tai prepo- sitio, jonka konkreettinen perusmerkitys ei vastaa Agricolan käyttämän adposition perusmerkitystä. Vain neljästi Agricola on kääntänyt latinan (ja kreikan) mallin mukaisesti ja poikennut saksannoksesta ja ruotsinnoksista. Latinankielinen käännös on toiminut mallina erityisesti Agricolan vastaan-adpositiorektiolle ja datiivigenetiivirektiolle. Agricolan teksteissä on valittu kuitenkin useammin ruotsin ja saksan mukainen päälle- tai ylitse-adpositio latinanmukaisen vastaanadposition sijasta. Myös osalle ylitseadpositioista on paralleeli latinassa.

Agricolan allatiivirektiota vastaavissa kohdissa on latinannoksissa, kreikankielisessä laitoksessa ja toisessa ruotsinnoksessa datiivirektio. Datiivirektiot olisivat tarjonneet mallin, jonka mukaan $\mathrm{Ag}$ ricola olisi voinut suomentaa useitakin kohtia allatiivilla, mutta käännöksissä on yleensä kuitenkin valittu adpositiorektio sijamuotorektion sijaan.

Tarkastelen seuraavaksi tutkimusaineistoni adpositio- ja sijamuotorektioita omissa luvuissaan. Koska adpositiorektiot ovat huomattavasti yleisempiä kuin sijamuotorektiot, aloitan niistä.

\section{Adpositio vihastumisverbin rektiona}

Päälle-adpositio on Agricolan kielessä yleisin vihastumista ilmaisevan verbin rektio (13 es.; ks. myös Salmi 2010: 248251). Rakenteista 11 esiintyy Raamatun teksteissä, ja niiden avulla voidaan parhaiten tarkastella erikielisten lähdetekstien vaikutusta Agricolan käännösratkaisuihin.

Vihastumisverbin rektiona oleva päälleadpositio (esim. 1) voi lähdetekstien perusteella olla saksannoksen ja ruotsinnosten interferenssiä. Lutherin saksannoksessa ärsykettä ilmaistaan überprepositiorakenteella ${ }^{9}$ ja ruotsinnoksissa över-, på- ja uppå-prepositiorakenteilla.

9. Lutherin tekstissä kirjoitusasu on vber, ruotsinnoksissa öffuer tai offuer ja vppå. 
Näiden prepositioiden perusmerkitys on 'päälle'. Adpositio päälle on päätynyt Agricolan teksteissä vihastumisverbin rektioksi lähdeteksteissä tässä funktiossa esiintyvien adpositiota perusmerkitykseltään vastaavien prepositioiden mallin mukaan. Vulgatassa on puolestaan vastaavissa kohdissa rektio, joka ei vastaa Agricolan päälle-adpositiota: contra-, in- ja ad-prepositiot sekä datiivi. Kaikista rektiona olevista päälle-adpositioista vain kaksi on Uudessa testamentissa. Niistä nähdään, ettei Agricola ole kääntänyt päälle-adpositiorektiota myöskään Erasmuksen latinannoksen eikä Erasmuksen kreikankielisen version mukaisesti, sillä niissä vihastumisen ärsykettä ilmaistaan datiivilla. ${ }^{10}$

Senteden mine kyrkestyin temen Sucucunnan päle / ia sanoin - (A-II-635-[Heb-3:10])

Minä vihastuin heidän sukupolveensa ja sanoin - - (R1992)

Darumb ich entrüstet ward / vber dis Geschlechte / vnd sprach $--(\mathrm{L})$

- - hwarföre wort iach thet slectit ogönstugh, och sadhe - - (NT)

Therföre wardt iagh wreedh $p a ̊$ thetta slechtet, och sadhe - (GVB)

propter quod infensus fui generationi huic et dixi - - (V)

Quapropter infensus eram generationi illi, \& dicebam - - (ER)

$\Delta$ ì̀ $\pi \rho \circ \sigma \omega ́ \chi \theta \iota \sigma \alpha \tau \tilde{\eta} \gamma \mathcal{\varepsilon} v \varepsilon \dot{\alpha} \dot{\varepsilon} \dot{\varepsilon} \kappa \varepsilon i v \eta \underline{\text {, }}$ кaì عĩ̃ov - - (KR)

Päälle vakiintui Raamatun kieleen vihastumista ilmaisevien verbien rektioksi vuoden 1776 raamatunsuomennokseen

10. Prepositiota ei ole myöskään ruotsinkielisessä Uudessa testamentissa (NT) esimerkissä 1. Tekstissä esiintyvän ogönstugh-sanan merkitys on 'ogunstig, ovänlig; otacksam' (Söderwall 18011900 s.v. ogönstogher [wgönstig]; vrt. myös ogönst 'ondt, förtret; misshag, ovilja' (mt. s.v. ogönst). asti (ks. taulukkoa 2 s. 226); se on jopa yleisempi Bibliassa ja vuoden 1776 raamatunkäännöksessä kuin Agricolalla. Vuosien 1933/38 raamatunsuomennoksessa sitä ei kuitenkaan enää esiinny. Allatiivi- ja illatiivirektio, jotka ovat korvanneet jo osan Biblian päälle-adpositiorektioista, ovat vuosien 1933/38 raamatunsuomennoksessa ja nykysuomennoksessa (1992) ainoita vihastumisverbien rektioita. Selityksen ärsykettä ilmaisevan päälle-adposition käytön häviämiseen tarjoaa purismi. 180o-luvulla vierasperäisiksi katsottuja adpositioita karsittiin tietoisesti kielestä. Useassa tuolloin ilmestyneessä kieliopissa todetaan, ettei päälle-adpositiota tule käyttää, mikäli pelkkä sijamuoto ilmaisee saman asian (ks. Renvall 1840: 125; Setälä 1880: 48; 1892: 114; ks. myös Merimaa 2002: 80-82). Ruotsinmukaisia ja suomen kieleen sopimattomia päälle-adpositiorakenteita listaa myös esimerkiksi Elias Lönnrot (1844: 183-191; 1857: 271-272).

Päälle-adpositiota käytetään Raamatussa vihastumista ilmaisevien verbien rektiona kieliopillisemmassa funktiossa kuin suomen kielessä alkuaan tai nykyään. Tämän tutkimuksen ulkopuolelle jää kuitenkin sen tarkastelu, onko omaperäinen motivaatio osaltaan vaikuttanut päälleadposition käyttöön ärsykkeen ilmaisimena.

Toiseksi yleisin vihastumista ilmaisevien verbien rektio on ylitse (9 es.). Ylitse-adposition käyttö tässä funktiossa selittyy lähdekielten interferenssillä. Ylitse-adpositiota vastaavissa kohdissa on Lutherin saksannoksen über-, ruotsin över- ja latinan super-prepositiot (esim. 2), jotka vastaavat perusmerkitykseltään ylitse-adpositiota ja ovat kieliopillistuneet lähdekielissä ilmaisemaan vihastumisen ärsykettä. Vain esimerkin 3 esiintymä on Uudesta testamentista. Se on ainoa, jolle lähin vastine lähdeteksteissä on ylitseadpositiorakennetta merkityksen ja rakenteen kannalta vastaava adverbi, Lutherin saksannoksessa darüber ja ruot- 
sinkielisessä kokoraamatussa (GVB) ther över. Kreikankielisen tekstin yhdysverbi sisältää ylitse-sanaa vastaavan yhdys-

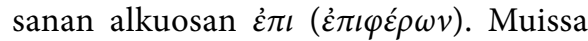
käännöksissä (NT, V ja ER) ei ilmaista ärsykettä. Muille kuin esimerkin 3 ylitseadpositiolle on lähdeteksteissä vastineena 'ylitse'-merkityksinen prepositio.

(2) HERRA / Mixi sinun wihas iulmastu ylitze sinun Canssas? (A-I-121-[2Ms-32:11])

Miksi, Herra, vihastuisit omaan kansaasi? (R1992)

Warumb wil dein zorn ergrimmen vber dein Volck (L)

Ah HERRE, hwj wil tijn wredhe förgrymma sigh öffuer titt folck (GVB)

cur Domine irascitur furor tuus contra populum tuum $(\mathrm{V})$

(3) Ongo sis Jumala wäre / ette hen sen ylitze wihastupi? (A-II424-[Rom-3:5])

Onko Jumala ehkä väärämielinen - puhun nyt ihmisten tavoin - kun hän antaa vihan

kohdata meitä? (R1992)

Ei kaiketi Jumala ole väärä, kun hän rankaisee vihassansa? (R1933/38)

Jst denn Gott auch vngerecht / das er darüber zürnet? (L)

Är tå Gudh oretferdugher som straffar? (NT)

Är tå Gudh oretferdigh som wredhgas ther offuer? (GVB)

- - numquid iniquus Deus qui infert iram - - (V)

- - num injustus Deus, qui inducat iram? (ER)

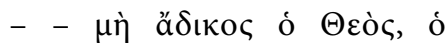

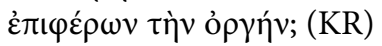

Agricolan $y$ litse-adpositioilla kääntämät kohdat on käännetty Bibliassa ja vuoden 1776 suomennoksessa päälle-adpositioilla (ks. taulukkoa 2 s. 226). Ylitse-adposition käyttö vihastumista ilmaisevien verbien rektiona rajoittuu siis Agricolan raamatunsuomennokseen.

Vihastumista ilmaisevien verbien rektioina olevat päälle- ja ylitse-adpositiot havainnollistavat mielenkiintoisella tavalla eri lähdetekstien vaikutusta Agricolan suomennokseen (ks. myös taulukkoa $3 \mathrm{~s}$. 227). Saksan über-prepositio on käännetty Agricolan teksteissä sekä päälle- että ylitseadpositiolla. Jos kohta, jossa Lutherin saksannoksessa on über-prepositio, on käännetty ruotsinkielisessä kokoraamatussa på- tai uppå-prepositiolla, Agricolan tekstissä on käytetty aina ruotsin mukaisesti päälle-adpositiota. Myös latinannoksella on ollut vaikutusta adposition valintaan: kaikki kohdat, joissa latinankielisessä lähdetekstissä on super-prepositio, on käännetty ylitse-adpositiolla. Näissä kohdissa saksannoksessa on über-prepositio ja ruotsinnoksessa över-prepositio, jotka molemmat voidaan suomentaa sekä päälle- että ylitse-adpositiolla. Vastineita on siis kahdessa tai kolmessa erikielisessä lähdetekstissä, mutta jokin yksittäinen teksti on ratkaissut, kumpi kahdesta läheisestä käännösvaihtoehdosta on valittu. Yhden lähdekielen ilmauksen polyseemisyys olisi mahdollistanut useamman käännösratkaisun, mutta toinen lähdekieli on ohjannut tiettyyn käännökseen.

Neljä kertaa Agricolan kielessä vihastumista ilmaisevan verbin rektiona esiintyy vastaan-adpositio (esim. 4). Nämä vastaan-adpositiot voivat lähdetekstien tarkastelun perusteella olla latinankielisten contra 'vastaan' ja adversus/adversum 'kohti, kohtaan, suhteen ${ }^{11}$-prepositioiden mallin mukaan käännettyjä. Myös ruotsinnoksessa on kerran emoot-prepositio, mahdollisesti latinan interferenssin vaikutusta sekin. Vastaan-adpositiorakenteet

11. Kohtaan-adpositio esiintyy jo Agricolan kielessä, mutta sitä ei ole käytetty vihastumista ilmaisevien verbien rektiona. 
on käännetty esimerkissä 4 Erasmuksen latinankielisen käännöksen iratus est adversus mukaisesti. Myös muissa lähdeteksteissä on vastaavassa kohdassa prepositio, mutta prepositioiden perusmerkitys poikkeaa Agricolan adposition perusmerkityksestä: über, på, över ja દ̇ $\pi i$ 'päälle', in 'sisässä, jossakin'.

(4) Ja se Lohikerme wihastui site Waimoa wastan - - (A-II695-[Ilm-12:17])

Lohikäärmeen raivo yltyi - (R1992)

Vnd der Drach ward zornig vber das Weib - - (L)

Och Draken wort wreedh emoot quinnonna - - (NT)

Och Draken wardt wreedh $p \stackrel{a}{a}$ quinnona - - (GVB)

et iratus est draco in mulierem $--(\mathrm{V})$

Et iratus est draco adversus mulierem - - (ER)

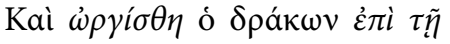

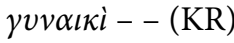

Agricolan vastaan-adpositioilla kääntämät kohdat on käännetty Bibliassa ja vuoden 1776 suomennoksessa päälleadpositioilla (ks. taulukkoa 2 s. 227). Vastaan-adpositiorakenne ilmaisee ärsykettä siis vain Agricolan käännöksessä.

Agricolan teksteissä ilmaistaan vihastumisen ärsykettä kerran myös vastoinadpositiorakenteella (esim. 5). Vastoin esiintyy Rukouskirjan kohdassa, jolle ei löydy Gummeruksen (1955) eikä Holman (2008) tutkimusten perusteella lähdetekstiä.

(5) Kienne minua HERRA sinun polehes / ja ele wihastu minua wastoin (A-I-739)

Vihastumista ilmaiseva verbi saa lisäksi Agricolan kielessä kaksi kertaa rektiokseen kanssa-adposition (esim. 6). Agricolan tekstejä ja lähdetekstejä vertaa- malla voi todeta, että rektioissa on kyse Lutherin saksannoksen ja ruotsinnoksen interferenssistä. Niissä esiintyvien prepositioiden mit ja medh perusmerkitys on 'kanssa', ja prepositiorakenteet ilmaisevat lähdeteksteissä ärsykettä. Vulgatassa on puolestaan käytetty adversumprepositiota.

(6) WAan nyt sine poissöxet ia poisheitet / Ja wihastut sinun woidheltus cansa. (A-III343-[Ps-89:39])

Kuitenkin sinä vihastuit voideltuusi, hylkäsit ja jätit hänet. (R1992)

ABer nu verstössestu vnd verwirffest / Vnd zürnest mit deinem Gesalbeten. (L)

MEn nu bortdriffuer tu och förjastar / och wredhgas medh tinom Smoorda. (GVB)

tu autem reppulisti et proiecisti iratus es adversum christum tuum (V)

Agricolan kanssa-adpositioilla kääntämät rektiot on käännetty Bibliassa ja vuoden 1776 suomennoksessa päälle-adpositioilla ja myöhemmin sijamuodoilla (ks. taulukkoa 2). Vaikka kirjoitetun kielen ohjailijat ja huoltajat ovat kokeneet vihastumisverbien rektioina olevat kanssa-adpositiot vieraiksi ja raamatunsuomentajat ovat kääntäneet kyseiset kohdat Agricolan jälkeen muulla tavoin, adposition käyttö tässä funktiossa on jäänyt elämään kansankieleen ja pysynyt näin yhtenä adposition käyttötapana. Kanssa-adpositiota käytetään Suomen murteiden sanakir$j a n^{12}$ (s.v. kanssa) mukaan seuraavasti: mut mnää oli niim pali kiukkune, niitte miästen kans. Lisätutkimusta kuitenkin

12. Muut adpositiot eivät esiinny vielä Suomen murteiden sanakirjan julkaistuissa sana-artikkeleissa, joten sanakirjan tietoja on mahdollista hyödyntää vain kanssa-adposition analyysissa. 
vaatisi, miten mahdollinen omaperäinen motivaatio on vaikuttanut kanssaadposition käyttöön ärsykkeen ilmaisimena ja miten se kietoutuu yhteen kontaktilähtöisen muutoksen kanssa. On mahdollista, että murteiden kanssa-adpositio on Raamatun kielen vaikutusta ja levinnyt vanhasta kirjakielestä puhekieleen.

\section{Sijamuoto vihastumisverbin rektiona}

Sijamuoto on Agricolan kielessä huomattavasti harvemmin vihastumista ilmaisevan verbin rektiona kuin adpositio. Kolme kertaa rektiona on allatiivi. Vihastumista ilmaisevien verbien allatiivirektion voi katsoa olevan omaperäinen, sillä yksi allatiivin perusfunktioista on ilmaista kohdetta eli sitä, johon asennoidutaan tai reagoidaan. Allatiivisija itsessään on kehittynyt jo myöhäiskantasuomen aikaan, ja se esiintyy edelleen nykysuomessa vihastumista ilmaisevien verbien rektiona (vihastua jollekin/jollekulle). Henkilöviitteistä allatiivia käytetään vuoden 1642 Bibliassa suurelta osin samalla tavalla kuin nykysuomessa (Leino, Herlin, Honkanen, Kotilainen, Leino \& Vilkkumaa 2001: 457). Agricolan allatiivilla kääntämät raamatunkohdat on kuitenkin 1900-luvun raamatunkäännöksissä suomennettu joko illatiivilla tai muunlaisella rakenteella (ks. taulukkoa 2 s. 226).

Myös osassa Agricolan lähdetekstejä esiintyy määrätyssä sijamuodossa oleva täydennys. Latinannoksissa, kreikankielisessä laitoksessa ja ruotsinkielisessä kokoraamatussa on datiivi (ks. esim. 7 qui-

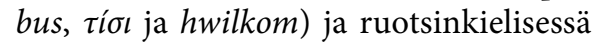
Uudessa testamentissa (NT) hwem. Agricola on käyttänyt allatiivirektiota myös kirjoittaessaan tekstiä suoraan suomeksi, kuten esipuhetta edustava esimerkki 8 osoittaa. Tämä tukee rakenteen tulkitsemista omaperäiseksi. Esimerkissä 7 on huomionarvoista myös se, että siinä esiintyy ajanilmaus neliekymende aiastaica, minkä vuoksi verbin merkitys on ennemmin staattinen 'vihata, olla vihoissaan' kuin inkoatiivinen 'vihastua, suuttua'.

(7) Mutta ioille sijs hen oli kyrkestynyt neliekymende aiastaica? (A-II-636-[Heb-3:17])

Keille Jumala oli vihoissaan neljäkymmentä vuotta? (R1992) Vber welche aber ward er entrüstet vierzig jar lang? (L) Men hwem war han ögonstugh $\mathrm{j}$ fyratyio åår? (NT)

Men hwilkom war han wreedh $\mathrm{j}$ fyratiyo åår? (GVB)

Quibus autem infensus est/fuit quadraginta annos/annis? (V; ER)

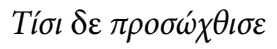

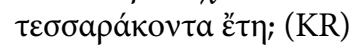

(8) Jonga cautta Jumala mielistupi Canssains cochtan / se on / eipe hen heille wihastu (A-III434-[Ps-149:0])

Kolmesti vihastumista ilmaisevan verbin rektiona on Agricolan kielessä illatiivi (esim. 9). Kuten allatiivilla, myös illatiivilla ilmaistaan suomen kielessä vanhastaan kohdetta, ja illatiivi on nykysuomessakin mahdollinen vihastumisverbin rektio. 1900-luvun raamatunsuomennoksissa nimenomaan illatiivi on ainoa aineiston vihastumista ilmaisevien verbien rektiosija (ks. taulukkoa 2). Agricolan käyttämissä lähdeteksteissä ei ole sijamuotorektioita illatiivirektiota vastaavissa kohdissa. Lutherin saksannoksessa on an- ja GVB:ssä til-prepositio ja Vulgatassa perusmuotoinen Sion. Myös lähdetekstien verbit poikkeavat rakenteeltaan ja merkitykseltään Agricolan käännöksestä. Lutherin saksannoksessa ja ruotsinkielisessä kokoraamatussa on hat ein ekel an ja haffuer een wämjelse til 'olla inho/vastenmielisyys jotakin kohtaan' ja Vulgatassa abominata 'manata pois, tor- 
jua luotaan, inhota, kirota' (Streng 1997 s.v. abominor).

(9) Ja swtucko sinun Sielus zionijn? (A-I-141-[Jer-14:19]) - - etkö lainkaan välitä Siionista? (R1992)

Oder hat deine Seele ein ekel an Zion? (L)

- - eller haffuer tijn siäl een wämtelse til Zion? (GVB)

- - aut Sion abominata est anima tua $(\mathrm{V})$

Vanhassa kirjasuomessa esiintyy paljon datiivigenetiiviä eli genetiivimuodon datiivista käyttöä. E. N. Setälän (1883: 42) mukaan datiivigenetiivi vastaa allatiivia ja omistajaa ilmaisevaa adessiivia, mutta sitä tulisi käyttää niiden asemesta vain, kun tarkoitetaan, että jollekulle tuleva tai jollakulla oleva on abstrakti (eikä käsin pideltävä). Nobufumi Inaban (2015: 313) mukaan suomen datiivigenetiivi on syntynyt ruotsin kielen vaikutuksesta. 1400-1500-luvuilla ruotsissa tapahtuneet sijamerkinnän muutokset välittyivät puhuttuun suomen kieleen. Ruotsin kielessä suora ja epäsuora objekti alettiin merkitä samalla sijamuodolla, ja toisaalta ruotsin datiivia ja uudemman sijajärjestelmän mukaista nominatiivi-akkusatiivia käytettiin rinnakkain ja sekaisin. Suomen kielessä persoonapronominit ja yksikölliset substantiivit puolestaan loivat mallin $n$-sija $=$ lle-sija, jossa genetiivi ja allatiivi jakoivat habitiivisen tulosijan tehtävän. Datiivigenetiivi on täten ruotsin mallin ja siitä kehittyneen suomen sisäisen mallin analogian aikaansaama laajennus (datiivigenetiivistä ks. myös P. Leino ym. 2001; J. Leino 2003).

Datiivigenetiivi esiintyy Agricolan kielessä yleisimmin verbin täydennyksenä. Myös ainoa vihastumisverbin rektiona oleva datiivigenetiivi (esim. 10) kuuluu tähän ryhmään, ja se vastaa allatiivia. (Inaba 2015: 55, 383.) Agricolan suomennoksen verbille läheisin vastine on ruotsinnoksen warda leedze widh, jolla ilmaistaan suuttumista. Agricolan datiivigenetiivin käyttö täydennyksen sijana puolestaan noudattaa saksan ja latinan genetiivin mallia. Esimerkki 10 kertoo kiinnostavalla tavalla Agricolan käännöstekniikasta: Erikieliset lähdetekstit ovat läsnä käännösprosessissa. Yhden lauseen sisällä näkyy useamman lähdetekstin vaikutusta, ja jopa niin kiinteät kokonaisuudet kuin vihastumista ilmaiseva verbi ja sen täydennys on voitu kääntää erikielisistä teksteistä. ${ }^{13}$

(10) Heiden pite nopiasti sen $\mathrm{Ku}$ ningan ia Pämiesten swttuman. (A-III-620-[Hos-8:10])

Kaikki he joutuvat Assyrian kuninkaan sorron alle ja hupenevat vähiin. (R1992)

- - ja he alkavat käydä vähäpätöisiksi ruhtinasten kuninkaan verojen painosta. (R1933/38)

Sie sollen der Last des Königs vnd der Fürsten bald müde werden. (L)

The skola snart leedze warda widh Konungens och förstarnas tunga. (GVB)

et quiescent paulisper $\mathrm{ab}$ onere regis et principum $(\mathrm{V})$

Agricolan kielessä esiintyy kerran myös vihastumisverbi, jolla on partitiivirektio (julmastua jotakuta). Vihastumisen ärsykettä ei ilmaista nykysuomessa partitiivilla, mutta vanhassa kirjasuomessa myös partitiivia voidaan käyttää datiivisesti kuten genetiiviä ja datiivia (Inaba 2000: 80). Seuraavan esimerkin vihastumisverbin partitiivirektio ei selity lähde-

13. Agricolan tekstien osalta on mahdollista laskea esimerkin 10 rakenne muiden rektiotapausten joukkoon, vaikka lähdekielten näkökulmasta rektio on hajotettu kääntämällä täydennys erikielisestä lähdetekstistä kuin verbi. 
tekstien avulla. Lähdeteksteissä vastaavassa kohdassa on vihastumisen sijaan inhoamista ilmaisevia verbejä. Inhoamisen kohdetta ei ilmaista kyseisten verbirakenteiden yhteydessä, vaan se käy ilmi edeltävästä tekstistä. Ruotsinkielisessä kokoraamatussa on stygges vid 'tuntea inhoa jotakuta kohtaan', Lutherin saksannoksessa hat einen grawen 'olla inho, kauhu, kammo' ja Vulgatassa abominatos 'inhota, manata pois, torjua luotaan, kirota' (Streng 1997 s.v. abominor). Mikäli julmastua-verbi ilmaisisi inhoamista, partitiivi olisi lauseessa objektin asemassa: inhota jotakuta. ${ }^{14}$

(11) Ja catzo meiden poolen / iotca ylencatzottut olema / ette iocaijnen meite iulmastu / Ette sijttekin pacanat ymmerdeisit / iottas meiden Jumala olet. (A-I-183-[2Mkk-1:27])

- - ja katso niitten puoleen, jotka ovat halveksittuja ja inhottuja, niin että pakanat tietäisivät, että sinä olet meidän Jumalamme. (R1933/38)

- - vnd sihe $v n s$ verachte an / da fur jederman einen grawen hat / Das doch die Heiden erfaren / das du vnser Gott seiest. (L) - - och see til oss som förachtadhe äro / ther hwar man stygges widh / på thet Hedhningarna doch förnimma mågha / at tu wår Gudh äst. (GVB)

- - qui serviunt gentibus contemptos et abominatos respice ut sciant gentes quod tu es Deus noster (V)

Agricolan kielessä on kolme vihastumista ilmaisevaa verbiä, jotka saavat ela-

14. Agricolan teksteissä esiintyy jonkin verran painovirheitä, joten ei ole mahdotonta, että meitäpartitiivin sijaan pitäisi olla esimerkiksi meistäelatiivi tai meitä vastaan -adpositiorakenne. tiivirektion. Rektio on mahdollinen myös nykysuomessa. Elatiivirektiota esiintyy aineistossa vuoden 1776 raamatunsuomennokseen asti, ja 1900-luvun raamatunsuomennoksissa on sen sijaan muunlainen suomennos (ks. taulukkoa 2 s. 226). Agricolan tekstien rakenteissa, joissa inkoatiivisen vihastumisverbin täydennyksinä on sekä kokija että ärsyke, ärsyke on miltei aina ihmistarkoitteinen, kuten taulukko 5 osoittaa. Elatiivimuotoinen täydennys poikkeaa muista täydennyksistä, sillä kaikki elatiivimuotoiset täydennykset ovat ei-ihmistarkoitteisia. Vastaavanlaisia ei-ihmistarkoitteisia täydennyksiä on myös ylitse- ja päälleadpositiorakenteissa.

\section{Taulukko 5.}

Vihastumista ilmaisevien verbien

täydennykset.

\begin{tabular}{l|r|r}
$\begin{array}{l}\text { Adpositio/ } \\
\text { sijamuoto }\end{array}$ & $\begin{array}{l}\text { Ihmis- } \\
\text { tarkoit- } \\
\text { teinen }\end{array}$ & $\begin{array}{l}\text { Ei-ihmis- } \\
\text { tarkoit- } \\
\text { teinen }\end{array}$ \\
\hline päälle & 12 & 1 \\
\hline ylitse & 6 & 3 \\
\hline vastaan/vastoin & 5 & \\
\hline Elatiivi & & 3 \\
\hline Allatiivi & 3 & \\
\hline Illatiivi & 3 & \\
\hline kanssa & 2 & \\
\hline Genetiivi & 1 & \\
\hline Partitiivi & 1 & \\
\hline Yhteensä & 33 & \\
\hline
\end{tabular}

Agricolan tekstien elatiivirektioiset kohdat ovat rakenteen kannalta vapaampia suomennoksia kuin monet edellä esitellyt rektiot, kuten esimerkki 12 osoittaa. Siinä Agricolan käännöksessä on eipe mine sijte swtu. Tekstissä täydennyksenä olevaa se-pronominia vastaava pronomini on lähdeteksteissä subjektina, kuten thet förtryter migh intet'se ei harmita minua?. 
(12) Ette mine teille ydhelle modholla kirioitan / eipe mine sijte swtu / waan se tekepi teite site wissimexi. (A-II-550-[Fil-3:1])

Das ich euch jmer einerley schreibe / verdreusst mich nicht / vnd machet euch deste gewisser. (L)

Thet iagh idher iw alt thet samma scriffuer, thet förtryter migh intet, men thet är idher testa tryggare. (NT)

At iagh idher jw alt thet samma scriffuar, thet förtryter migh intet, men thet gör idher thes wissare. (GVB)

eadem vobis scribere mihi quidem non pigrum vobis autem necessarium $(\mathrm{V})$

eadem scribere vobis, me quidem haud piget, vobis autem tutum est. (ER)

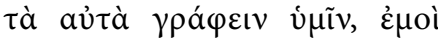

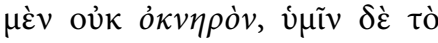

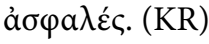

Elatiivin semanttinen rooli poikkeaa jonkin verran muiden rektioina olevien sijamuotojen ja adpositiorakenteiden semanttisista rooleista. Tämä näkyy siinä, että elatiivimuotoinen sana voi esiintyä saman verbin rektiona kuin muussa sijassa oleva sana tai adpositiorakenne olematta rinnasteinen sen kanssa, kuten vihastua jostakin jollekulle. Semanttisten roolien erojen selvittäminen olisi mielenkiintoinen jatkotutkimuksen aihe.

\section{Lopuksi}

Tutkimuksen perusteella vihastumista ilmaisevien verbien rektioissa tapahtuu diakroninen muutos adpositiorektioista sijamuotorektioihin, kun siirrytään Agricolan teksteistä nykysuomeen. Agricolan teksteissä vihastumista ilmaisevien verbien rektiona on tyypillisesti adpositio, mutta myös sijamuotorektioita esiintyy; vuoden 1642 Bibliasta vuoden 1776 raamatunsuomennokseen rektioina ovat adpositio ja sijamuodot ja nykysuomessa yksinomaan sijamuodot. Jo Agricolan teksteissä kuitenkin esiintyvät samat sijamuotorektiot kuin nykysuomessakin. Niille ei ole osoitettavissa mallia lähdeteksteistä; ainoastaan nykysuomessa esiintymätön datiivigenetiivi on kielikontaktilähtöinen sijamuotorektio. Agricolan lähdetekstiuskollisuus selittää adpositioiden käyttöä ja käytön runsautta vihastumisverbien rektioina, ja sijamuotorektioita näyttääkin esiintyvän Raamatun sijaan vapaammissa käännöksissä ja suoraan suomeksi kirjoitetuissa osissa - Rukouskirjassa, esipuheissa ja muissa teoksissa kuin Raamatussa olevissa raamatunkohdissa - mikä tukee päätelmiä adpositiorektioiden kontaktisyntyisyydestä.

Useimmissa Agricolan tekstien adpositiorektioissa on kyse lähdetekstien aiheuttamasta interferenssistä, jossa kohdekielessä jo olemassa oleviin adpositioihin on liitetty uusia funktioita lähdekielen prepositioiden mallin mukaan. Agricola näyttää seuranneen käännöksissään erityisesti ruotsin- ja saksankielisiä lähdetekstejä. Useimmat rektiona olevat adpositiot esiintyvät vain Agricolan teksteissä, ja jo vuoden 1642 Bibliassa kaikki ylitse-, vastaan- ja kanssaadpositiorektiot on käännetty muulla tavoin, esimerkiksi sijamuotorektioilla. Päälle-adpositio on poikkeus. Se on säilynyt Raamatun kielessä vihastumisverbien rektiona 1700-luvun loppupuolelle saakka. Myös päälle-adpositio kuitenkin häviää kielestä vihastumisverbin rektion asemasta, ja syynä tähän lienee se, että erityisesti 1800 -luvulla pyrittiin tietoisesti karsimaan kielestä vierasperäisiä rakenteita, joihin monien adpositiorektioiden katsottiin lukeutuvan. Tietoinen kielenhuolto ja kielen "suomalaistaminen" ovat siis osaltaan vaikuttaneet Bibliasta alkaen rakenteiden käyttöön. Vihastumisverbien rektioina olevista adpositioista poikkeuk- 
sellinen on myös kanssa, joka esiintyy suomen murteissa vanhaa kirjasuomea vastaavassa funktiossa, kuten olla kiukkuinen jonkun kanssa, vaikkei sitä kirjakielessä enää tavatakaan. Interferenssin lisäksi omaperäinen motivaatio on voinut vaikuttaa siihen, että alkuaan spatiaalisilla adpositioilla on alettu ilmaista kieliopillisempaa suhdetta, vihastumisen ärsykettä. Tässä tutkimuksessa ei ole kuitenkaan ollut mahdollista perehtyä mahdollisen omaperäisen motivaation vaikutukseen.

Tutkimukseni osoittaa, että vaikka jollekin rakenteelle voi olla käännösvastine useammassakin eri lähdetekstissä, on tapauksia, joissa jokin yksittäinen lähdekieli on ollut ratkaiseva sen suhteen, kumpi kahdesta käännösvaihtoehdosta on valittu. Edellä esitetyt päälle- ja ylitseadpositiokäännökset havainnollistavat tätä hyvin. Tutkimukseni vahvistaa tietämystä Agricolan käännöstekniikasta mutta antaa myös uutta tietoa erityisesti erikielisten lähdetekstien merkityserojen hienovaraisesta huomioimisesta käännöstyössä. Tällaiset lähdekielten vaikutukset saadaan esille vain, kun tarkastellaan kohdetekstin kaikkia samassa funktiossa käytettäviä rakenteita ja kaikissa lähdeteksteissä esiintyviä rakenteita rinnakkain.

HeIdI SALMI etunimi.sukunimi@utu.fi

Kirjoittaja on suomen kielen yliopisto-opettaja Turun yliopistossa.

\section{Aineistolähteet}

A = Mikael Agricolan teokset 1-4. Uudistettu näköispainos. WSOY, Porvoo 1987 ja tekstikorpus Mikael Agricolan teokset 1-4. Kotimaisten kielten keskus, Helsinki. Korpus sisältää Agricolan teosten 1. uudistetun näköispainoksen vuodelta 1987 ja sisältyy kokoelmiin Vanhan kirjasuomen korpus: Agricola. http:// kaino.kotus.fi/korpus/vks/meta/agricola/ agriırk1_rdf.xml (20.5.2017).

Biblia 1776. http://www.finbible.fi/head/bibl. htm. (20.6.2017).

Biblia, Se on Coco Pyhä Raamattu 1642. Kotimaisten kielten keskus, Helsinki. Sisältyy kokoelmiin Vanhan kirjasuomen korpus Biblia: http://kaino.kotus.fi/korpus/ vks/meta/biblia/biblia_coll_rdf.xml (24.7.2017).

$\mathrm{ER}=$ Desiderii Erasmi Roterdami opera omnia VI. Lugduni Batavorum 1705. Näköispainos. The Gregg Press Limited, London 1962. Sisältää Erasmuksen latinankielisen Uuden testamentin käännöksen.

GVB = Nya Testamentet $i$ Gustaf Vasas Bibel under jämförelse med texten av år 1526, utgivet av Natan Lindqvist. Stockholm 1941 ja Vanhan testamentin osalta Biblia, Thet är, All then Helgha Scrifft, på Swensko. Tryckt j Upsala 1541.

$\mathrm{KR}=$ Desiderii Erasmi Roterdami opera omnia VI. Lugduni Batavorum 1705. Näköispainos. The Gregg Press Limited, London 1962. Sisältää Erasmuksen julkaiseman kreikankielisen Uuden testamentin vuoden 1535 laitoksena.

L = Luther, Martin D. 1545: Die gantze Heilige Schrifft Deudsch. Wittenberg. Herausgegeben von Hans Volz unter Mitarbeit von Heinz Blanke. Textredaktion Friedrich Kur. München 1972.

Mikael Agricolan teosten morfosyntaktinen tietokanta. Työryhmä Nobufumi Inaba, Heidi Merimaa, Kirsi-Maria Nummila \& Tanja Vaittinen. Hankkeen johtaja Kaisa Häkkinen. 2004-2007. Lauseopin arkisto, Turun yliopisto ja Kotimaisten kielten keskus, Helsinki.

NT = Thet Nyia Testamentit på Swensko af år 1526. Ånyo utgifvet af Aksel Andersson. Uppsala 1893.

R1933/38 = Raamattu 1933/1938. http://www. evl.fi/raamattu (24.7.2017).

R1992 = Pyhä Raamattu. Vanha testamentti. Uusi testamentti. Suomen evankelis-luterilaisen kirkon kirkolliskokouksen vuonna 1992 käyttöön ottama suomennos. 
http://www.evl.fi/raamattu (24.7.2017).

$\mathrm{V}=$ Hieronymi Vulgata. . http://www.intratext. com/X/LATooo1.htm (20.6.2017).

\section{Kirjallisuuslähteet}

Gummerus, Ja a ko 1955: Mikael Agricolan Rukouskirja ja sen lähteet. Suomen Kirkkohistoriallisen Seuran toimituksia XLIV. Helsinki: Suomen Kirkkohistoriallinen Seura.

Heininen, Simo 1992: Mikael Agricolan psalmisummaariot. Suomi 166. Helsinki: Suomalaisen Kirjallisuuden Seura.

- 1993: Mikael Agricolan Vanhan testamentin summaariot. Suomi 169. Helsinki: Suomalaisen Kirjallisuuden Seura.

— 1999: Mikael Agricola raamatunsuomentajana. Helsinki: Suomalaisen Kirjallisuuden Seura.

Hjelt, Arthur 1909: Mikael Agricola Uuden Testamentin kääntäjänä. Juhlaesitelmä Suomen Kirkkohistoriallisen Seuran vuosikokouksessa 19. p. tammik. 1908. Helsinki: Suomen Kirkkohistoriallinen Seura.

Holma, Juhani 20o8: Sangen ialo Rucous. Schwenckfeldiläisten rukouskirja Mikael Agricolan lähteenä. Helsinki: Yliopistopaino.

HäKKINEN, KAISA 1994: Agricolasta nykykieleen. Suomen kirjakielen historia. Helsinki: WSOY.

_ 2007: Suomalainen kirjallisuus Ruotsin vallan aikana. - H. K. Riikonen, Urpo Kovala, Pekka Kujamäki \& Outi Paloposki (toim.), Suomennoskirjallisuuden historia I s. 24-33. Helsinki: Suomalaisen Kirjallisuuden Seura.

Inaba, Nobufumi 2000: Genetiivin ja partitiivin datiivinen käyttö vanhassa kirjasuomessa. Sijamerkinnän ja sijajärjestelmän suhteesta. - Sananjalka 42 s. 47-86.

- 2015: Suomen datiivigenetiivin juuret vertailevan menetelmän valossa. SuomalaisUgrilaisen Seuran Toimituksia 272. Helsinki: Suomalais-Ugrilainen Seura.
Itkonen-Kaila, Marja 1997: Mikael Agricolan Uusi testamentti ja sen erikieliset lähtötekstit. Suomi 184. Helsinki: Suomalaisen Kirjallisuuden Seura.

— 2007: Mikael Agricola suomentajana. - H. K. Riikonen, Urpo Kovala, Pekka Kujamäki \& Outi Paloposki (toim.), Suomennoskirjallisuuden historia I s. 56-59. Helsinki: Suomalaisen Kirjallisuuden Seura.

Kela, MARIA 2007: Jumalan kasvot suomeksi. Metaforisaatio ja erään uskonnollisen ilmauksen synty. Jyväskylä Studies in Humanities 82. Jyväskylä: Jyväskylän yliopisto.

Kolehmainen, Leena - Nordlund, TARU 2011: Kielellinen muutos tutkimuksen kohteena. Kieltenvälinen vertailu, kieliopillistuminen ja kielikontaktien tutkimus. - Virittäjä 115 s. 5-35.

LAitinen, LeA 2004: Grammaticalization and standardization. - Olga Fischer (toim.), Up and down the cline. The nature of grammaticalization s. 247-262. Philadelphia: John Benjamins Publishing Company.

LEINO, JА А Kо 2003: Antaa sen muuttua. Suomen kielen permissiivirakenne ja sen kehitys. SKST 9oo. Helsinki: Suomalaisen Kirjallisuuden Seura.

Leino, Pentti - Herlin, Ilona - HonKanen, Suvi - Kotilainen, Lari - Leino, JaAkKo - Vilkkumaa, MAIJA 2001: Roolit ja rakenteet. Henkilöviitteinen allatiivi Biblian verbikonstruktioissa. SKST 813. Helsinki: Suomalaisen Kirjallisuuden Seura.

LÖNNROT, Elias 1844: Muukalaisuudesta Suomessa. Suomi 1844. - Raija Majamaa (toim.), Elias Lönnrot. Valitut teokset 3. Kirjoitelmia ja lausumia s. 183-196. SKST 551. Helsinki: Suomalaisen Kirjallisuuden Seura 1991.

— 1857: Kauppakamari ja maakamari uudesti suomennetut. Suomi 1857. Raija Majamaa (toim.), Elias Lönnrot. Valitut teokset 3. Kirjoitelmia ja lausumia 
s. 271-298. SKST 551. Helsinki: Suomalaisen Kirjallisuuden Seura 1991.

MerimaA, Heidi 2002: Adpositiot suomen vanhoissa kieliopeissa. Pro gradu -tutkielma. Turun yliopiston kieli- ja käännöstieteiden laitos.

Murmann, Maximilian 2018: Inchoative emotion verbs in Finnish. Argument structures and collexemes. Helsinki: Helsingin yliopisto. http://urn.fi/ URN:ISBN:978-951-51-4192-7.

Paulasto, Heli - Kolehmainen, Leena

- Kumpulainen, Minna - MeriLÄInen, LEA - RiIonheimo, Helka 2014: Interferenssi - termi tutkimussuuntausten törmäyksessä. - Virittäjä 118 s. $408-434$.

Renvall, Gustaf 1840: Finsk Språklära, Enligt den rena Vest-Finska, i Bokspråk vanliga Dialecten. Åbo.

RiIonheimo, Helka 2007: Muutoksen monet juuret. Oman ja vieraan risteytyminen Viron inkerinsuomalaisten imperfektinmuodostuksessa. SKST 1107. Helsinki: Suomalaisen Kirjallisuuden Seura.

2013: Multiple roots of innovations in language contact. Evidence from morphological intermingling in contact between Ingrian Finnish and Estonian. - Studies in Language 37 s. 645-674. Amsterdam: John Benjamins Publishing Company.

Salmi, Heidi 2010: Mikael Agricolan teosten kielen ala-, ylä- ja pää-vartaloiset adpositiot. Turun yliopiston julkaisuja C 307. Turku: Turun yliopisto. http://urn.fi/ URN:ISBN:978-951-29-4506-1.

Schmeidler, Marie-Elisabeth 1970 : Sprachliche Analyse des MatthäusEvangeliums, Kapitel 1-2, in der Übersetzung von Michael Agricola.

- Congressus tertius internationalis fenno-ugristarum I s. 362-368. Tallinn.

SEtäl Ä, E. N. 1880: Suomen kielen lauseoppi. Oppikirjan koe. Helsinki: K. E. Holm. 1883: Lauseopillinen tutkimus Koillis-
Satakunnan kansankielestä. Helsinki:

Suomalaisen Kirjallisuuden Seuran

kirjapaino.

— 1892: Finska språkets satslära till läroverkens tjenst. Helsingfors: Söderström \& c:o.

Sirroinen, MARi 2001: Kuka pelkää, ketä pelottaa. Nykysuomen tunneverbien kielioppia ja semantiikkaa. SKST 854. Helsinki: Suomalaisen Kirjallisuuden Seura.

SSA = Suomen sanojen alkuperä. Etymologinen sanakirja I-III. Kotimaisten kielten tutkimuskeskuksen julkaisuja 62 . Helsinki: Kotimaisten kielten tutkimuskeskus 1992-2000.

SKST = Suomalaisen Kirjallisuuden Seuran Toimituksia.

Suomen murteiden sanakirja I-VIII. Kotimaisten kielten tutkimuskeskuksen julkaisuja 36. Helsinki: Kotimaisten kielten tutkimuskeskus 1985-2008.

Streng, Adolf V. 1997: Latinalais-suomalainen sanakirja. SKST 196. Helsinki: Suomalaisen Kirjallisuuden Seura.

SöDerwall, K. F. 1891-1900: Ordbok öfver svenska medeltids-språket. Lund: Berlingska boktryckeri- och stilgjuteriaktiebolaget.

TARKiAinen, Viljo - TARKiAinen, KARi 1985: Mikael Agricola, Suomen uskonpuhdistaja. Helsinki: Otava.

Thomason, SARAH G. 2001: Language contact. An introduction. Washington, D.C.: Georgetown University Press.

VISK = HAKULINEN, AUli - Vilkuna, Maria - Korhonen, Rittta Koivisto, Vesa - Heinonen, TARja Rittta - Alho, Irja 2004: Iso suomen kielioppi. Helsinki: Suomalaisen Kirjallisuuden Seura. Verkkoversio. Saatavissa: http://scripta.kotus. fi/visk URN:ISBN:978-952-5446-35-7. (30.8.2018.)

VKS = Vanhan kirjasuomen sanakirja. I-II (A-K). Kotimaisten kielten tutkimuskeskuksen julkaisuja 33. Helsinki: Kotimaisten kielten tutkimuskeskus \& Painatuskeskus/Edita 1985 ja 1994. 